\title{
Effect of monsoon on zooplankton variations and environmental characteristics in a tropical fish pond at Aligarh, India.
}

\section{Hesham Reda Abdel Mola ${ }^{1}$ and Saltanat Parveen ${ }^{2}$}

1- National Institute of oceanography and fisheries, 101 Kasr El-Einy st., Cairo, Egypt.

2- Limnology Lab, Department of Zoology, Aligarh Muslim University, India. * E-mail: hesham reda06@yahoo.com

\begin{abstract}
The phsico-chemical parameters and zooplankton abundance were analyzed monthly in Lal Diggi pond at Aligarh, India during the period from October, 2010 to August, 2011. High variations of zooplankton and water quality were observed in the pond. Thirty nine species were identified belonging to Copepoda (3 species), Rotifera (27 species), Cladocera (6 species) and Protozoa (3 species). Copepoda formed the highest percentage of zooplankton $(66.65 \%)$, followed by Cladocera $(14.93 \%)$, Rotifera $(9.61 \%)$ and Ostracoda $(8.61 \%)$, while Nematoda and Protozoa formed the lowest dominant groups being $0.15 \%$ and $0.05 \%$ respectively. The principal component analysis was conducted to clear the correlation between zooplankton and the environmental factors. Due to the disturbance effect on the pond, the biotic indices recorded a relatively decrease during monsoon in June and July and start to increase during August. The authors suggested that, using the pond for fish culture, especially, after monsoon for six months (from October to March) because it has the best water quality and zooplankton productivity during this period.
\end{abstract}

Keywords: Zooplankton, phsico-chemical parameters, biotic indices, Lal Diggi pond, India.

\section{INTRODUCTION}

Ponds in India, directly or indirectly, have an enormous ecological, commercial and socio-economic importance. They are rich in components of bio-diversity, like, flora and fauna of local, natural and regional significance. Thus, the ponds play an important role in conserving biodiversity (Ghanai et al., 2010). Also, the natural ponds are estimated to have an area of about 0.72 million ha, most of them are found in the vicinity of villages, places of religious worship and other human inhabitations (Kamat and Sima, 2000; Shiddamallayya and Pratima, 2008; Rajagopal et al., 2010). This makes them quite vulnerable to changes day by day, which would probably give a clear picture about the pollution stress on them (Isaiarsu and Mohandoss, 1998; Raja et al., 2008). Monsoon plays a very important role in the environmental state of the ponds (Parveen and Mola, 2013). The monsoon season is followed by a period of transition from rainy to dry and cool weather. This is the season of retreating monsoon and is termed as post-monsoon. This season is characterized by a further fall in diurnal and nocturnal temperatures and a gradual decrease in photoperiod and relative humidity.

Zooplankton diversity responds rapidly to changes in the aquatic environment. Several zooplankton species have served as a bioindicators 
(Ahmad et al., 2011; Mola, 2011) and thus is a well suited tool for understanding water pollution studies (Ahmad, 1996). Studies on planktonic composition and morphometric, physical and chemical characteristics of water bodies are necessary to obtain basic knowledge on the biodiversity in ponds (Rajagopal et al., 2010). Fresh water zooplankton comprises principally rotifers, cladocerans, copepods and protozoans. Zooplankton communities often respond quickly to environmental change because most species have short generation cycle (usually days to weeks).

The aim of the present work is to study some physico-chemical parameters, zooplankton population and diversity indices of Lal Diggi pond in Aligarh, India. Behind the above task, the correlation coefficient matrix and some statistical analyses between these physico-chemical parameters and the dominant zooplankton groups and species will be conducted to substantiate results in the pond.

\section{MATERIALS AND METHODS}

\section{Study area:}

Aligarh, a district of Uttar-Pradesh in Northern India, is located in the central Ganga-Yamuna Doab at latitude $27^{\circ} 54^{\prime} \mathrm{N}$ and longitude $78^{\circ} 4^{\prime} \mathrm{E}$. The Climatology experiences the tropical monsoon type of climate with marked North-East and SouthWest monsoons. The year can be broadly divided into five seasons; winter (December to January), spring (February to March), summer (April to June), Monsoon season i.e. season of general rains (July to September) and Post-monsoon season (October to November). Lal Diggi pond is a perennial freshwater, sewage-fed pond and is situated in the residential area of Aligarh. The depth of the pond varies from 0.8 to $3.0 \mathrm{~m}$ in different seasons. The basin of the pond is more or less flat which is marshy in nature consisting of organic matter, decayed leaves sand, humus, clay, gravels. The drainage system of the pond constitutes of four inlet drains which carry the waste water and sewage from the surrounding localities.

\section{Collection and analysis of samples:}

Water samples were collected from the pond monthly from October, 2010 to August, 2011. Air and water temperature were measured using a mercury thermometer graduated to $100{ }^{0} \mathrm{C}$. Transparency of water was determined using Secchi Disk. Electrical conductivity (EC) was measured in $\mu \mathrm{mS} / \mathrm{cm}$ by the conductivity meter. Hydrogen ion concentration $(\mathrm{pH})$ was directly measured by $\mathrm{pH}$ meter. All the chemical parameters were determined according to (APHA, 2005).

Zooplankton was collected by filtration of 20 Litters from the water column with plankton net (mesh size $55 \mu \mathrm{m}$ ). All samples were fixed in $4 \%$ formalin. In the laboratory, the samples were examined, counted, classified, identified and described according to description and keys constructed by Needham and Needham (1966), Pennek (1978) and Shehata et al. (1998 a \& b). Statistical analyses of biological indices were conducted with PRIMER 5 (version 5.2.0) software and the correlation coefficient between different physico-chemical parameters and the dominant zooplankton species was carried out by SPSS (version 12) software. Principal corresponding analysis was conducted by XL STAT program, 2014. 


\section{RESULTS AND DISCUSSION}

\section{1- Physico-chemical parameters}

The variation in water temperature (Table 1) usually follows air temperature. It was recorded the highest during summer $\left(31{ }^{0} \mathrm{C}\right)$ on monsoon during June, July and August and the lowest during winter $\left(17{ }^{0} \mathrm{C}\right)$. The highest reading of transparency was recorded during March $(30 \mathrm{~cm})$, this might be due to settlement of sediment while the lowest reading was recorded during summer $(10 \mathrm{~cm}$ in June) which might be due to evaporation of ponds water, which causes concentration of dissolved solids and increasing of temperature and production of plankton. Similar observations were recorded by Kaushik \& Saksena (1999) and Parveen \& Mola (2013). The lowest value of $\mathrm{pH}$ (8.1) was recorded during July. The relative decrease of $\mathrm{pH}$ values in this pond might be due to the effect of inflowing wastewater sewage effluent throughout the year (Ahmad et al., 2012) and the highest average of $\mathrm{pH}(8.8)$ was recorded during winter.

Dissolved oxygen was recorded lower values during spring, being 0.8 $\mathrm{mgl}^{-1}$. This might be attributed to the input of sewage and agricultural wastes, as biochemical decomposition of organic matter leads to increasing ammonia and sulphids production during mineralization of organic matter which lead to enormous oxygen depletion. Similar observations were given by Emam (2006). The highest value $\left(6.7 \mathrm{mgl}^{-1}\right)$ was recorded during Post-monsoon in November. This may be due to the abundance of phytoplankton which enriched water with oxygen during photosynthesis activity (Parveen \& Mola, 2013). Electrical conductivity and chloride concentration ranged between 808-1585 mgl $\mathrm{m}^{-1}$ and 49.63-100.68 $\mathrm{mgl}^{-1}$ respectively then reached to their maximum values during summer due to the evaporation effect. The lowest values might be due to the replenishment of rains during monsoon season. This coincided with Ahmad et al. (2012). Bicarbonate concentrations also followed the same pattern of distribution in the pond. Higher values of carbonate during winter months might be due to input of detergents and lower values in monsoon months and were found to be mainly due to higher turbidity and low transparency values (Rajagopal et al., 2010).

The absence of carbon dioxide during the most studied months might be due to the presence of carbonates or high values of $\mathrm{pH}$ ( 8.3 or above). Kaushik and Saksena (1999) have also recorded absence of $\mathrm{CO}_{2}$ due to similar reasons. The highest values of carbonate were recorded during winter being 54 and $58 \mathrm{mgl}^{-1}$ in May and June respectively, while the highest values of carbon dioxide were recorded during January and February being 57 and $79 \mathrm{mgl}^{-1}$ respectively. This might be due to the abundant of macrophytes in the pond. This observation agreed with Singhal (1991). Dissolved oxygen (DO) varied from 0.8 in April to $6.7 \mathrm{mg} / \mathrm{l}$ in November. Fluctuations in DO concentrations have been found to be affected by many factors like solubility of oxygen in water, intensity of light and photosynthesis (Ahmad et al., 2011). Due to the effect of high temperature, as it has no replenishment, the water level recorded lowest and the other salts increased during summer season (Parveen \& Mola (2013). From the present data, the water quality showed a remarkable enhancement and the salts decreased again during June, July and August due to the effect of heavy rains on monsoon. 
Table 1: Physico-chemical parameters in Lal Diggi pond during the period from October, 2010 to August, 2011.

\begin{tabular}{|l|c|c|c|c|c|c|c|c|c|c|}
\hline $\begin{array}{l}\text { Mont } \\
\text { h }\end{array}$ & $\begin{array}{c}\text { Air } \\
\text { Temp }\end{array}$ & $\begin{array}{c}\text { Wat. } \\
\text { Temp }\end{array}$ & Transparency & $\mathbf{E C}$ & $\mathbf{p H}$ & $\mathbf{C O}_{\mathbf{3}}$ & $\mathbf{H C O}_{\mathbf{3}}$ & $\mathbf{C O}_{\mathbf{2}}$ & $\mathbf{D . O}$ & $\mathbf{C l}$ \\
\hline Oct. & 28 & 25 & 25 & 1079 & 8.7 & 10 & 190 & 0 & 3.60 & 79.23 \\
\hline Nov. & 18 & 19 & 22 & 1195 & 8.4 & 0 & 232 & 9 & 6.70 & 68.06 \\
\hline Dec. & 21 & 17 & 22 & 1325 & 8.8 & 18 & 247 & 0 & 2.30 & 85.08 \\
\hline Jan. & 18 & 19 & 25 & 1270 & 8.8 & 0 & 292 & 57 & 1.50 & 82.24 \\
\hline Feb. & 19 & 17 & 27 & 1377 & 8.8 & 0 & 300 & 79 & 1.60 & 77.99 \\
\hline March & 29 & 26 & 30 & 1547 & 8.7 & 19 & 335 & 0 & 2.40 & 86.50 \\
\hline April & 31 & 29 & 20 & 1585 & 8.1 & 24 & 306 & 0 & 0.80 & 85.08 \\
\hline May & 34 & 30 & 12 & 1603 & 8.5 & 54 & 306 & 0 & 6.50 & 100.68 \\
\hline June & 32 & 31 & 10 & 1551 & 9.0 & 58 & 292 & 0 & 4.45 & 69.48 \\
\hline July & 33 & 31 & 20 & 1099 & 8.0 & 35 & 189 & 0 & 2.10 & 60.97 \\
\hline Aug. & 32 & 31 & 20 & 808 & 8.2 & 18 & 181 & 0 & 2.15 & 49.63 \\
\hline
\end{tabular}

\section{2- Zooplankton abundance and distribution}

In the present study, thirty nine species were identified in Lal Diggi pond belonging to Copepoda (3 species), Rotifera (27 species), Cladocera (6 species) and Protozoa ( 3 species). This pond considered lowest in species diversity but it has moderate density of zooplankton (535 Org. $\mathrm{l}^{-1}$ ) comparing to the nearest other ponds e.g. Chautal pond (1083 Org..$^{-1}$ ) and Medical pond ( 896 Org..$\left.^{-1}\right)$. The low numbers of zooplankton species in the pond might be due to the fluctuations of $\mathrm{pH}$ values and the deficiency of dissolved oxygen (Parveen and Mola, 2013). The average lowest abundance of zooplankton was observed in November (32 Org..$^{-1}$ ), while the highest was observed during April (1710 Org..$^{-1}$ ). Mageed (2005) claimed that certain deaths occurred due to stresses by high $\mathrm{pH}$, which had also a synergistic action upon zooplankton together with ammonia. Also, there is a direct relationship between temperature increase in water and the increase in zooplankton. Copepoda formed the highest percentage of zooplankton $(66.65 \%)$, and was followed by Cladocera (14.93 $\%)$, Rotifera (9.61 \%) and Ostracoda (8.61 \%) while Nematoda and Protozoa formed the lowest dominant groups being 0.15 and $0.05 \%$ respectively (Fig. 1).

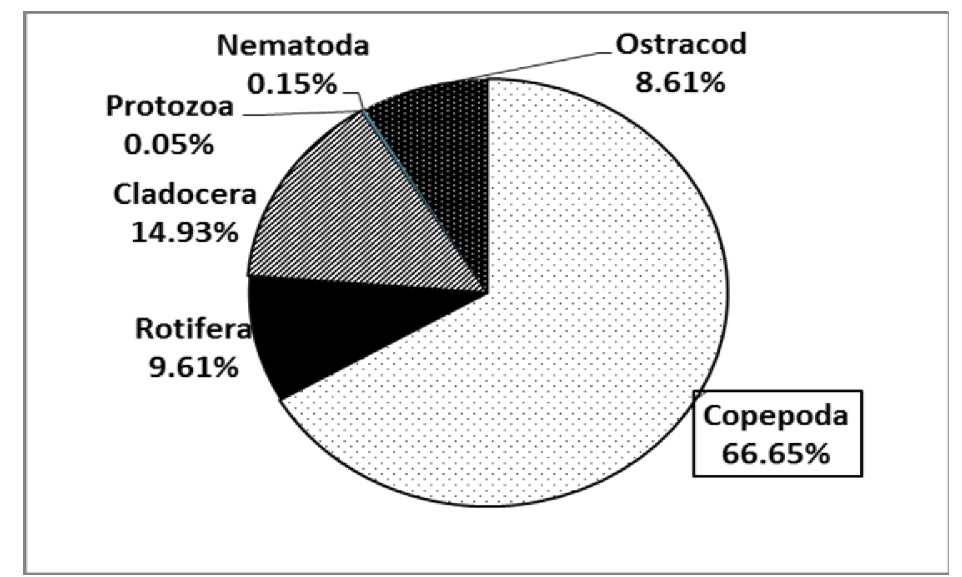

Fig.1: percentage frequency of the dominant zooplankton groups in Lal Diggi pond during the study.

Copepoda formed the third most abundant group of zooplankton density. It was represented by Cyclops, Mesocyclops and Diaptomus. The population density ranged between 69 Org. $1^{-1}$ in October and 10181 Org. $1^{-1}$ in April. El-serafy et al. (2009) mentioned that the domination of copepod is an indicator to a good water quality. 
Nauplius larvae recorded the highest bulk of copepods in the pond. The presence of this larva in all stations indicated that it has the ability to tolerat pollution (Emam, 2006). Only two species; Mesocyclops sp. and Cyclops sp. dominated during the study, while Diaptomus sp. dominated during Monson season in June, July and August being 160, 53 and 10 Org. $^{-1}$ respectively (Tables 2\&3). El-Serafy et al. (2009) mentioned that Copepoda was the most dominant group in Lake Nasser, Egypt that attributed to the good environmental conditions of the lake.

The highest density of Cladocera was during Post-monsoon in the pond and during spring due to domination of Ceriodaphnia cornuta (1540 Org. $\mathrm{l}^{-1}$ ). The highest abundance might be attributed to macrophytes. This observation coincided with Bozkurt and Guven (2009) who stated that the abundance of Cladocera in the vegetated areas was higher than unvegetated areas. Although, Daphnia sp. is known as winter form, it was recorded its highest occurrence during August (370 Org. $\left.\mathbf{l}^{-1}\right)$, which always rainy and cloudy during monsoon. Alam et al. (2008) mentioned that the maximum abundance of Daphnia sp. was recorded during winter and recorded a remarkable decrease during spring and was completely absent in the rest of the year. Also, the cladoceran Alona sp., Chydorus sphaericus, Diaphanosoma excisum and Simocephalus vetulus were recorded with low numbers.

Rotifera showed the highest number of species $(27$ species $)$ among zooplankton during study. Brachionus urceolaris, Monstyla closterocerca and Philodina roseola were the abundant rotifers. Five species of genus Brachionus, namely $B$. angularis, $B$. Calyciflorus, $B$. patulus, $B$. quadridentatus and $B$. urceolaris were recorded during the study. This is indication to the eutrophication of the pond. This observation agreed with Ahamed (2011) and Parveen \& Mola (2013).

The highest density of ostracods was recorded during June and July being 1270 and 808 Org. $1^{-1}$, respectively. Ostracoda was represented by the genera Cypris sp. and Cypriodopsis sp. Though these are benthic in nature but became planktonic due to disturbances in water because of continuous rains during these months of monsoon which brings them to surface water. Nematoda and Protozoa are considered the less dominant groups during the study. Nematoda recorded with low number (30 Org..$\left.^{-1}\right)$ during January and February and decreased during June (10 Org..$\left.^{-1}\right)$. It was completely absent in the rest of the year. Also, Ahmad et al. (2012) and Parveen \& Mola (2013) referred to the higher density of ostracods and nematods due to the mixing of epibenthic forms from sediment phase, which is rich with these animals during sampling. Protozoa (13 Org. $\left.1^{-1}\right)$ recorded only during July. It was represented by 3 species namely Arcella areniata, $A$. discoides and Centropyxis aculeate. Singh (2009) mentioned that the increasing of organic substances accompanied with increasing of Protozoa. 
Table 2: Monthly Variations of the dominant groups in Lal Diggi pond during the period from October, 2010 to August, 2011.

\begin{tabular}{|l|c|c|c|c|c|c|c|}
\hline & Copepoda & Rotifera & Cladocera & Protozoa & Nematoda & Ostracoda & Average \\
\hline Oct. & 69 & 234 & 0 & 0 & 0 & 6 & $\mathbf{5 2}$ \\
\hline Nov. & 151 & 30 & 0 & 0 & 0 & 9 & $\mathbf{3 2}$ \\
\hline Dec. & 231 & 6123 & 0 & 0 & 0 & 3 & $\mathbf{1 0 6 0}$ \\
\hline Jan. & 444 & 771 & 3 & 0 & 30 & 3 & $\mathbf{2 0 9}$ \\
\hline Feb. & 5700 & 5 & 2750 & 0 & 30 & 0 & $\mathbf{1 4 1 4}$ \\
\hline March & 1275 & 0 & 33 & 0 & 0 & 30 & $\mathbf{2 2 3}$ \\
\hline April & 10181 & 9 & 45 & 0 & 0 & 24 & $\mathbf{1 7 1 0}$ \\
\hline May & 420 & 1755 & 63 & 0 & 0 & 195 & $\mathbf{4 0 6}$ \\
\hline June & 510 & 230 & 10 & 0 & 10 & 1270 & $\mathbf{3 3 8}$ \\
\hline July & 133 & 13 & 840 & 13 & 0 & 808 & $\mathbf{3 0 1}$ \\
\hline Aug. & 280 & 70 & 420 & 0 & 0 & $\mathbf{1 0}$ & $\mathbf{1 4 0}$ \\
\hline Average & $\mathbf{1 7 6 3}$ & $\mathbf{8 4 0}$ & $\mathbf{3 7 9}$ & $\mathbf{1}$ & $\mathbf{6}$ & $\mathbf{2 2 0}$ & $\mathbf{5 3 5}$ \\
\hline
\end{tabular}

Table 3: Monthly Variations of the most frequented species in Lal Diggi pond during the period from October, 2010 to August, 2011.

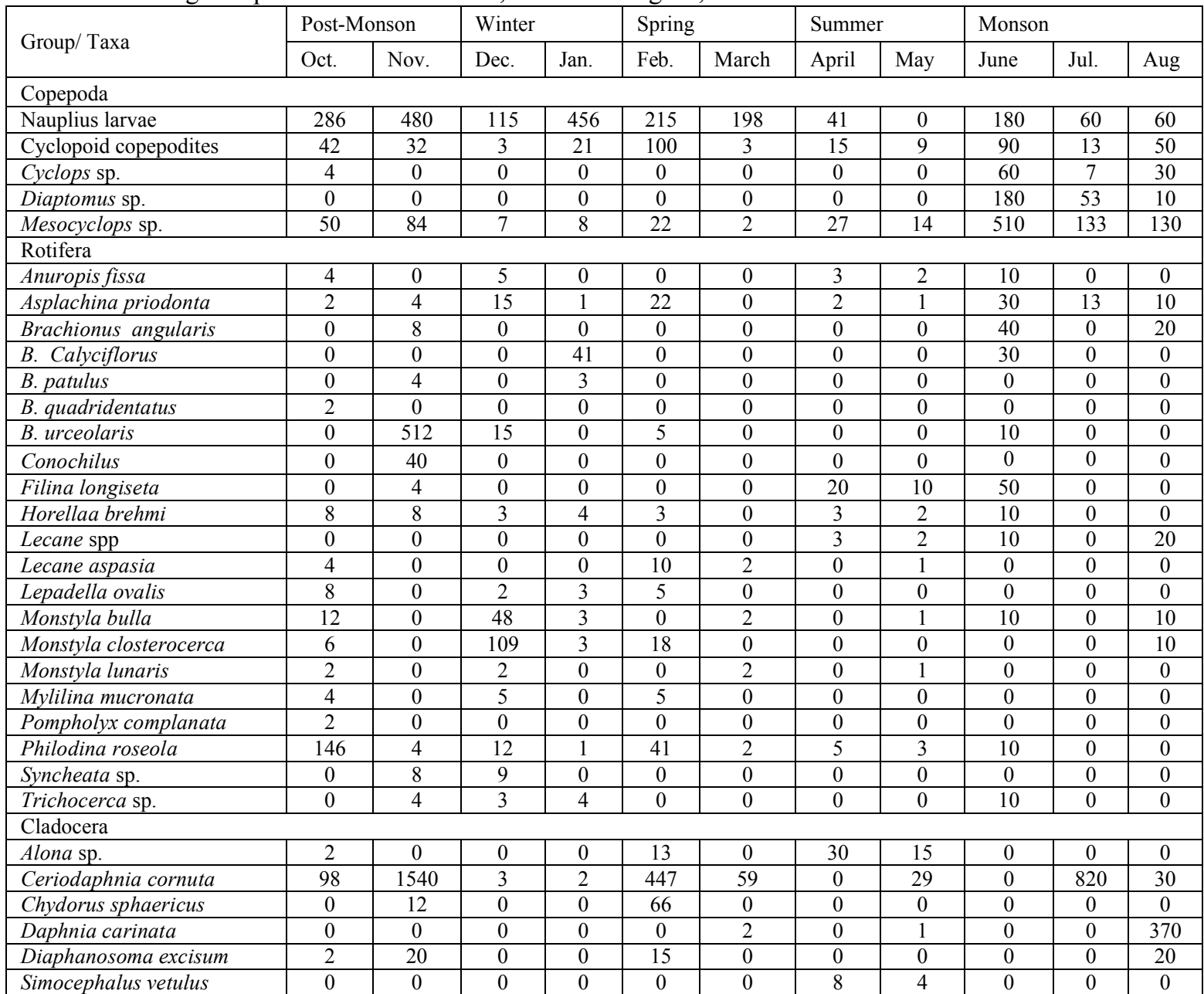

\section{3- Principal component analysis and correlation coefficient matrix}

Correlation coefficient matrix and principal component analysis was conducted for studying the effect of physic-chemical parameters on zooplankton (Fig. 2). The highest negative correlation was showed between Nematoda and $\mathrm{CO}_{3}(-0.55)$. This indicates that this zooplankton group can tolerate high organic pollution. Also, the 
present study revealed that Ostracoda recorded a significant positive correlation $r=$ 0.737 with $\mathrm{CO}_{3}$ and negative correlation $\mathrm{r}=-0.67$ with transparency. Parveen and Mola (2013) recorded low values of dissolved oxygen with high number of ostacods indicating that it can tolerate the deficiency of DO at high temperature. Dugel et al. (2008) mentioned that ostracods are widely distributed in all type of aquatic environment and water temperature, dissolved oxygen and electrical conductivity are the most effective factors influencing species composition of ostracods. Transparency recorded a positive correlation with Cladocera and Copepoda. Similar correlations were recorded by Mageed and Heikal (2005). Patalas and Salki (1992) found that high temperature affects physiology of several living organisms and their distribution. The principal component analysis showed a high positive correlation for Brachionus calyciflorus with transparency and the negative for Ceriodaphnia sp., with bicarbonate.

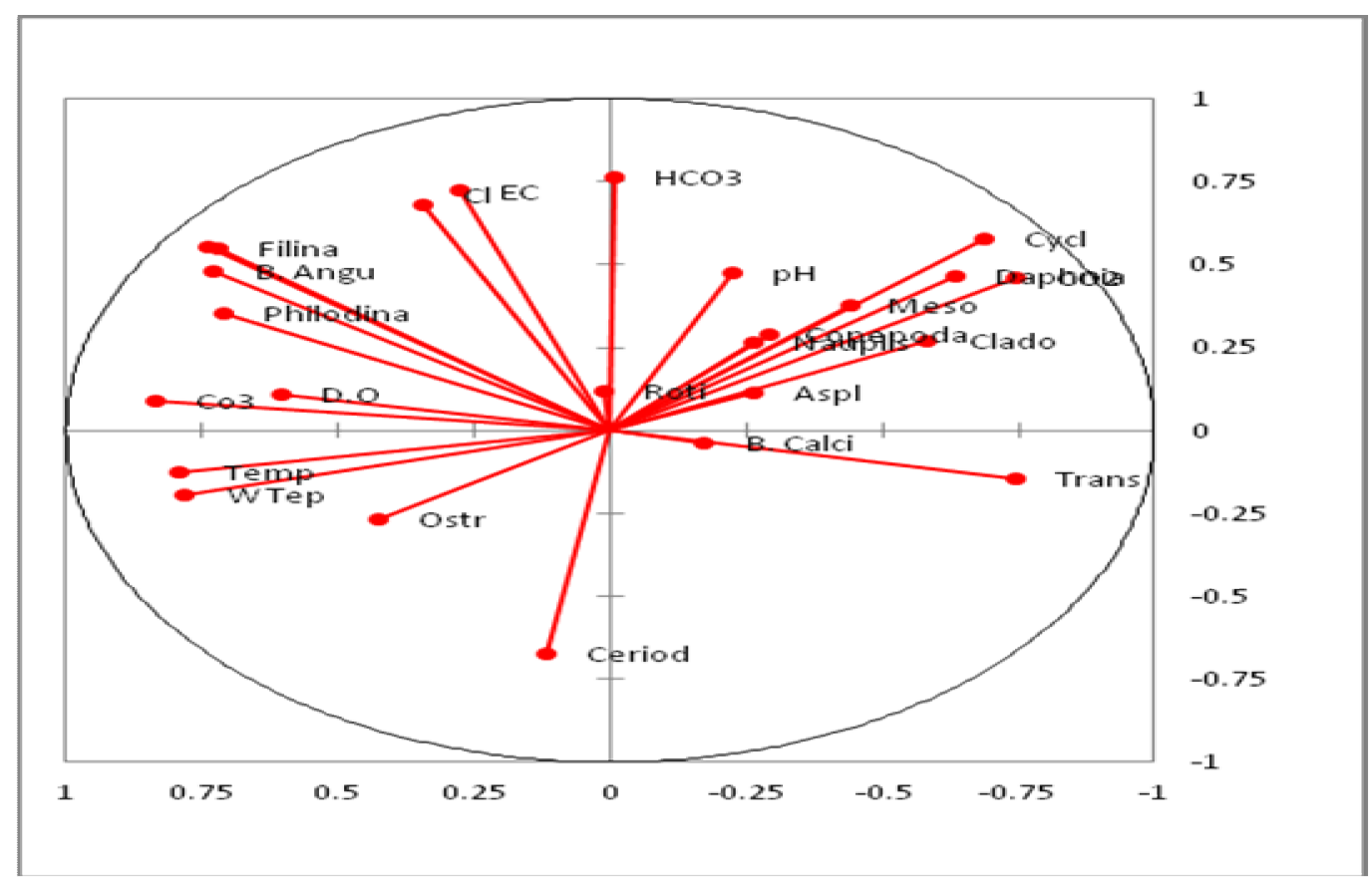

Fig. 2: Principal component analysis (PCA) was conducted for physico-chemical parameters and zooplankton during the study.

Cycl $=$ Cyclopoid copepodite, Roti $=$ Rotifera, Clado=Cladocera, Meso= Mesocyclops sp., Ceriod= Ceriodaphnia sp., Ostr= Ostracoda, Filina $=$ Filina longiseta, B. Angu= Brachionus angularis, B. Cali $=$ B. Calyciflorus, Temp $=$ Air temperature, $\mathrm{W}$ temp $=$ Water temperature, $\mathrm{D} . \mathrm{O}=$ Dissolved oxygen, Trans $=$ Transparency, EC= Electrical conductivity.

\section{4- Diversity indices}

In all recorded months, zooplankton species richness was found to be high in June during Monsoon season (2.63) than any other month. Dash (1996) reported that the higher in value of Shannon's index, the greater is the planktonic diversity. Bajpai and Agarker (1997) reported that the species diversity would be low following the disturbance such as flood. In the present study, the highest diversity indices were recorded during winter in January being $0.71,1.98,2.01$ and 0.84 for Evenness, Brillouin, Shannon and Simpson indices, respectively (Table 4). 
Table 4: Monthly Variations of biological Indices in Lal Diggi pond during the period from October, 2010 to August, 2011.

\begin{tabular}{|l|c|c|c|c|c|c|c|}
\hline Group & $\begin{array}{c}\text { Total } \\
\text { Species }\end{array}$ & $\begin{array}{c}\text { Total } \\
\text { Individuals }\end{array}$ & $\begin{array}{c}\text { Species } \\
\text { Richness }\end{array}$ & Evenness & Brillouin & Shannon & Simpson \\
\hline Oct. & 12 & 313 & 1.91 & 0.62 & 1.47 & 1.54 & 0.64 \\
\hline Nov. & 8 & 184 & 1.34 & 0.76 & 1.51 & 1.58 & 0.74 \\
\hline Dec. & 7 & 6354 & 0.69 & 0.17 & 0.33 & 0.33 & 0.13 \\
\hline Jan. & 17 & 1251 & 2.24 & 0.71 & 1.98 & 2.01 & 0.84 \\
\hline Feb. & 6 & 8485 & 0.55 & 0.51 & 0.91 & 0.91 & 0.52 \\
\hline March & 4 & 1308 & 0.42 & 0.21 & 0.28 & 0.29 & 0.11 \\
\hline April & 7 & 10244 & 0.65 & - & - & - & - \\
\hline May & 17 & 2238 & 2.07 & 0.69 & 1.92 & 1.94 & 0.79 \\
\hline June & 21 & 2030 & 2.63 & 0.60 & 1.80 & 1.83 & 0.70 \\
\hline July & 13 & 1814 & 1.60 & 0.53 & 1.34 & 1.35 & 0.64 \\
\hline Aug. & 15 & 770 & 2.11 & 0.72 & 1.91 & 1.95 & 0.79 \\
\hline
\end{tabular}

Parveen and Mola (2013) observed the highest values of biotic indices during summer (Pri-Monsoon season) which indicates that species are more evenly distributed in this pond. Similar observations were recorded by Kucznska-Kippen \& Basinska (2008) who mentioned that the highest diversity index of the crustacean community was found among submerged vegetation in summer months. The biotic indices recorded a relatively decrease during monsoon in June and July and started to increase during August. This agrees with Rajagopal et al. (2010). They reported that the low value of Shannon's index of plankton population in rainy season is due to dilution of water medium. Dash (1996) reported that the low values of Shannon's index were recorded during September, may be due to high downpour recorded as $244.2 \mathrm{~mm}$.

\section{CONCLUSION}

The presence of five species of Brachionus indicates that this pond is approaching towards eutrophication and is organically polluted. Different species of zooplankton showed their abundance according to the favorable condition, so they disappear in unfavorable conditions and reappeared on return of favorable condition after monsoon. The pond can be managed for fish culture, especially, for air breathing fishes like Heteropenuste fossils and Clarias batrachus after monsoon for six months (from October to March) because it recorded good water quality and suitable water level during this period.

\section{ACKNOWLEDGMENTS}

This work was funded by Center for International Cooperation in Science (CICS), India. The authors thank Prof. Asif A. Khan, Ex. Dean of Faculty of life Sciences, Aligarh Muslim University, India for his help and support during this work.

\section{REFERENTES}

APHA (American Public Health Association) (2005). Standard methods for examination of water and wastewater. 21st Edn. Standard Methods is a joint publication of the American Public Health Association (APHA), the 
American Water Works Association (AWWA), and the Water Environment Federation (WEF). Washington DC, USA.

Ahmad, M.S. (1996). Ecological survey of some algal flora of polluted habitats of Darbhanga. J. Environ. Pollut., 3: 147-151.

Ahmad, U., S. Parveen, A.A. Khan, H.A. Kabir, H.R.A. Mola and A.H. Ganai (2011). Zooplankton population in relation to physico-chemical factors of a sewage fed pond of Aligarh (UP), India. Biol. Med., 3 (2): 336-341.

Ahmad, U., S. Parveen, H.R. Abdel Mola, H.A. Kabir and A.H. Ganai (2012). Zooplankton population in relation to physico-chemical parameters of Lal Diggi pond of Aligarh (UP), India. J. Environ. biol., 33 (6): 10151019.

Alam, A., A.A. Khan and R.K. Gaur (1995). Observations on the alternate cladocern peaks in an eutrophic freshwater pond. Pure and Applied Sciences, 14 (2): 77-78.

Bajpai, A.K. and M.S. Agarker (1997). Lower plants at high Altitutes, I. Some plankton from Auli Skiing field. Ecol. Environ. Conser., 3: 97-100.

Bozkurt, A. and S. E. Guven (2009). Zooplankton composition and distribution in vegetated and unvegetated area in three reservors in Hatay, Turkey. Journal of Animal and Veterinary Advances, 8 (5): 984-994.

Dash, M.C. (1996). Fundamentals of ecology. Tata McGraw Hill Publishing Company limited, New Delhi.

Dugel, M., O. Kulkoyluoglu, M. Kilie (2008). Species assemblages and habitat preferences of Ostracoda (Crustacea) in Lake Abant (Bolu, Turkey). Belg. J. Zool., 138 (1): 50-59.

Emam, W. (2006). Preliminary study on the impact of water pollution in ElRahawy drain dumping in Rosetta Nile branch on zooplankton and benthic invertebrates. M. Sc. Thesis, Zoo. Dept. Fac. Sci. Ain Shams University (Egypt), $32 \mathrm{pp}$.

El-Serafy, S.S., A.A. Mageed and H.R. El-Enany (2009). Impact of flood water on the distribution of zooplankton in the main chaneel of Lake Nasser, Egypt. J. Egypt. Acad. Soc. Environ. Develop. 10 (1), 121-141.

Ganai, A.H., S. Parveen and A.A. Khan (2010). Study of some physicochemical parameters in Medical pond, Aligarh. The Ekologia, 10 (1): 89-96.

Isaiarasu, L. and A. Mohandoss (1998). Hydrobiological survey in ponds around Sivakasi. The Proceeding of National Symposium on Environment Biology. P. 212. St. XaviersCollege, Palayamkottai, India.

Kamat, S. and V. Sima (2000). Hydrobiological studies of two temple ponds in Ponda Taluka, Goa. Ecol. Environ. Cons., 6: 361-362.

Kaushik, S. and D.N. Saksena (1999). Physico-chemical limnology of certain water bodies of central India. In: Freshwater Ecosystem of India (Ed. K. Vijaykumar). Daya Publishing House, New Delhi, pp. 1-58.

Kucznska-Kippen, N. and A. Basinska (2008). Spatio-Temporal distribution of zooplankton between macrophyte and open water zones of Lake Wasowskie.

Mageed, A.A. (2005). Effect of some environmental factors on the biodiversity of holozooplankton community in Lake Qarun, Egypt. J. Aquat. Res., 31: 230-234.

Mola, H.R. (2011). Seasonal and spatial distribution of Brachionus (Pallas, 1966; Eurotatoria: Monogonanta: Brachionidae), a bioindicator of eutrophication in lake El-Manzalah, Egypt. Biology and Medicine, 3 (2): 60-69.

Needham, J.G. and P.R. Needham (1962). A Guide to the Study of the Freshwater Biology. Holden-Dey Inc., Francisco, pp. 108. 
Parveen S. and H.R. Mola (2013). Comparison of physico-chemical parameters and zooplankton species diversity of two perennial ponds in Aligarh, India. J. Environ. biol., 34(4): 709-716.

Patalas, K. and A. Salki (1992). Crustacean plankton in Lake Winmpeg. Variations in space and time as a function of lake morphology, geology and climate. Can. J. Fish. Aquat. Sci., 49 (5): 1035-1059.

Pennak, R.W. (1978). Freshwater Invertebrates of United States. (2nd Ed). John Wiley \& So Pejler, B. (1946)-Regional ecological studies of Swedish fresh water zooplankton. Zool.bidrag.uppsala, 36: 407-515.

Raja, P., A.M. Amarnath, R. Elangovan and M. Palanivel (2008). Evaluation of physical and chemical parameters of river kaveri, Tiruchirappalli, Tamil Nadu, India. J. Environ. Biol., 29: 765-768.

Rajagopal, T., A. Thangamani and G. Archunan (2010). Comparison of physicochemical parameters and phytoplankton species diversity of two perennial ponds in Sattur area, Tamil Nadu. J. Environ. Biol., 31 (5): 787-794.

Shehata, S.M.A., K.K Shehata, M.M. Hussien and A.A Mageed (1998a). Taxonomy, population structure, and species diversity of Rotifera in the high Dam Lake. Egypt J. Aquat. Biol. \& Fish., 2 (1): 1-36.

Shehata, S.M.A., K.K Shehata, M.M. Hussien and A.A Mageed (1998b). Taxonomical and ecological studies on some zooplankton species: Ciliata, Rhizopoda, Turbellaria and Crustacea of the High Dam Lake. Egypt $J$. Aquat. Biol. \& Fish., 2(1): 37-63.

Shiddamallayya, N. and M. Pratima (2008). Impact of domestic sewage of fresh water body. J. Environ. Biol., 29: 303-308.

Singhal, P.K. (1991). Distribution and abundance of the macrobenthic fauna in certain semi-arid fresh water bodies. Ph. D. thesis, Department of zoology, University of Jodhpur, Jodhpur (India), pp.244.

Singh, K. (2009). Studies on the impact assessment of post Lake Management operations in Upper Lake with special reference to zooplankton. $\mathrm{PhD}$ Thesis, Department of Limnology, Barkatullah University, Bhopal, India, pp.146.

\section{ARABIC SUMMARY}

$$
\begin{aligned}
& \text { تأثثر موسم الفيضان علي تنوع الهائمات الحيوانية والخصائص البيئية في أحد البرك السمكية بأليجار- الهند }
\end{aligned}
$$

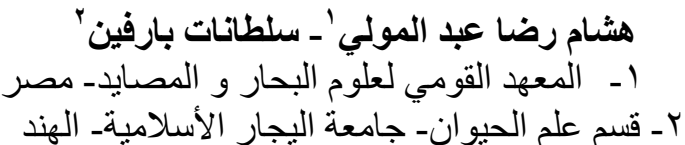

تم تحليل الخصائص الفيزيائية و الكيميائية ووفرة الهائمات الحيو انية شهريا في هذه البركة خلال الفترة

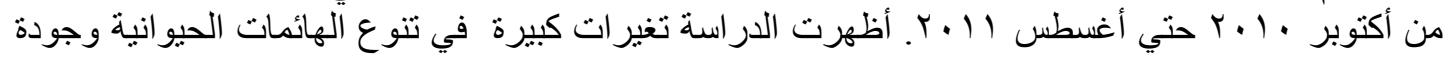

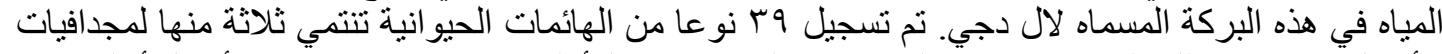

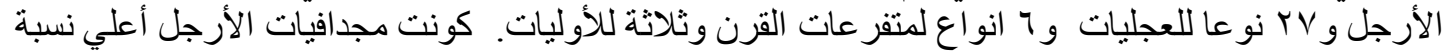

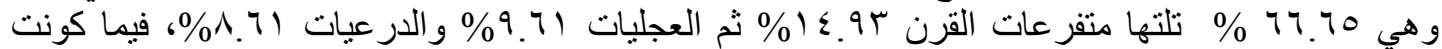

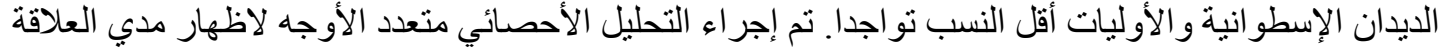

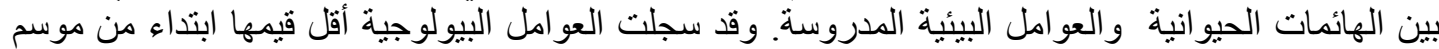

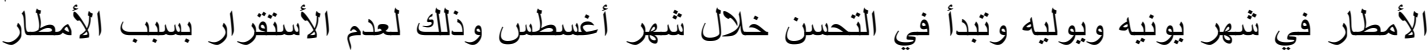

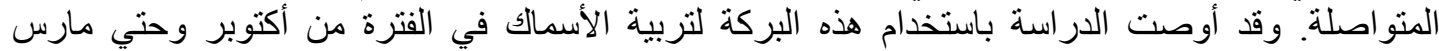
لتسجيلها أفضل جودة للمياه وخصوبة في الهائمات الحيو انية. 